\title{
Education and Social Mobility: New Analytical Approaches
}

Breen, Richard; Karlson, Kristian Bernt

Published in:

European Sociological Review

DOI:

10.1093/esr/jct025

Publication date:

2014

\section{Document version}

Early version, also known as pre-print

Document license:

Unspecified

Citation for published version (APA):

Breen, R., \& Karlson, K. B. (2014). Education and Social Mobility: New Analytical Approaches. European Sociological Review, 30(1), 107-118. https://doi.org/10.1093/esr/jct025 


\title{
Education and Social Mobility: New Analytical Approaches
}

\author{
Authors: Richard Breen and Kristian Bernt Karlson (kbk@soc.ku.dk)
}

THIS PAPER IS PUBLISHED IN

EUROPEAN SOCIOLOGICAL REVIEW

2014, vol. 30, no. 1, pp. 107-18

Access paper here:

http://esr.oxfordjournals.org/content/30/1/107

\section{Please notice: According to SHERPA/ROMEO, this paper cannot be archived in the university database. Please access the paper via the link to the publisher provided above.}

\begin{abstract}
This article develops tools for measuring the role of education in intergenerational social class mobility. Sociologists have long sought a method of decomposing the log odds-ratios involving class origins and destinations into a direct part and an indirect part mediated by education. Drawing on recent work we, first, present such a method and, second, suggest ways in which researchers might summarize the mediating role played by education. We apply these methods to examine whether education has come to play an increasing role in intergenerational social class mobility in Britain during the 20th century. Our results suggest that the mediating role of education did not change across the 20th century: roughly half of the association between class origins and destinations is mediated via educational attainment.
\end{abstract}

